\title{
Kapcsolat a szénhidrát-, és a zsírbevitel valamint a szív- és érrendszeri betegségek és mortalitásuk között, öt kontinens 18 országában (PURE): prospektív kohorszvizsgálat - a szerzők észrevételekre adott válaszai
}

\author{
Associations of fats and carbohydrates with cardiovascular disease and \\ mortality-PURE and simple? - Authors' reply
}

Ismerteti: $\quad$ Erdei Gergő $\square$

Országos Gyógyszerészeti és Élelmezés-egészségügyi Intézet

Szerzők: Mahshid Dehghan, Andrew Mente, Xiaohe Zhang, et al.

Megjelenés: Lancet DOI: https://doi.org/10.1016/S0140-6736(18)30774-8

Beküldve: 2018. 05. 16.

doi: 10.24365/ef.v59i3.310

Kulcsszavak: zsír, szénhidrát, szív- és érrendszeri betegségek, mortalitás, stroke

Keywords: fat, carbohydrate, cardiovascular disease, mortality, stroke

\begin{abstract}
A korábban megjelent tanulmány elsődleges célja volt, hogy értékelje a zsír-, (teljes, telített és telítetlen) és a szénhidrátbevitel, valamint a szív- és érrendszeri megbetegedések közötti összefüggést (a hivatkozott cikk itt elérhető: Kapcsolat a szénhidrát-, és a zsírbevitel valamint a szív- és érrendszeri betegségek és mortalitásuk között, öt kontinens 18 országában (PURE): prospektív kohorszvizsgálat ismertetése - cikkismertetés). A másodlagos cél az volt, hogy megvizsgálják a kapcsolatot a tápanyagok és a szív- és érrendszeri betegségek valamint a nem kardiovaszkuláris megbetegedések mortalitása között. A szakmai cikkel kapcsolatban számtalan észrevételt kaptak a szerzők.
\end{abstract}

$\mathrm{Az}$ eredmények konzisztensnek mondhatóak a korábbi tanulmányok eredményeivel. A publikáció- ban leírt magas zsírbevitel nem jelent egészségi problémát a korábbi vizsgálatok alapján. A „Women's Health Initiative” elnevezésű vizsgálat, amely 49000 nő bevonásával valósult meg, nem mutatott ki egészségi előnyöket alacsony zsírtartalmú étrend esetében a myocardialis infarktus, stroke és mortalitás esetében. A „PREDIMED” elnevezésű vizsgálat azt mutatta, hogy a mediterrán diéta összevetve az alacsony zsírtartalmú étrenddel csökkentette a szív-érrendszeri megbetegedések és a halálozások számát. A fentiek tükrében tehát elmondható, hogy sem a cohort, sem pedig a randomizált vizsgálatok nem támogatják az alacsony zsírtartalmú étrendet. A beszámoló további részeiben a szerzők kielégítő választ adnak az egyes felvetésekre.

\section{TANULSÁGOK A HAZAI SZAKEMBEREK SZÁMÁRA}

A szerzők korábban arról számoltak be, hogy a jelen vizsgálat és a témában készült más vizsgálatok eredményeinek tükrében a globális táplálkozási irányelvek újragondolása szükséges, amely mellett a szakemberek észrevételi mellett továbbra is kitartanak. 